\title{
Core I gene is overexpressed in Hürthle and non-Hürthle cell microfollicular adenomas and follicular carcinomas of the thyroid Valdemar Máximo ${ }^{1}$, Ana Preto ${ }^{1}$, Ana Crespo ${ }^{1,2}$, Ana Sofia Rocha1, José Carlos Machado ${ }^{1,3}$, Paula Soares ${ }^{1,3}$ and Manuel Sobrinho-Simões*1,3,4
}

\begin{abstract}
Address: ${ }^{1}$ Institute of Molecular Pathology and Immunology of the University of Porto (IPATIMUP), Porto, Portugal, ${ }^{2}$ Infection and Immunity Group, Gulbenkian Institute of Science, Oeiras, Portugal, ${ }^{3}$ Department of Pathology, Medical Faculty of Porto, Porto, Portugal and ${ }^{4}$ Department of Pathology, São João Hospital, Porto, Portugal

Email: Valdemar Máximo - vmaximo@ipatimup.pt; Ana Preto - apreto@ipatimup.pt; Ana Crespo - acrespo@ipatimup.pt; Ana Sofia Rocha - srocha@ipatimup.pt; José Carlos Machado - josem@ipatimup.pt; Paula Soares - psoares@ipatimup.pt; Manuel SobrinhoSimões* - ssimoes@ipatimup.pt

* Corresponding author
\end{abstract}

Published: 25 March 2004

BMC Cancer 2004, 4:12
Received: 18 November 2003

Accepted: 25 March 2004

This article is available from: http://www.biomedcentral.com/I47/-2407/4/12

(C) 2004 Máximo et al; licensee BioMed Central Ltd. This is an Open Access article: verbatim copying and redistribution of this article are permitted in all media for any purpose, provided this notice is preserved along with the article's original URL.

\begin{abstract}
Background: Most of the steps involved in the initiation and progression of Hürthle (oncocytic, oxyphilic) cell carcinomas of the thyroid remain unknown.

Methods: Using differential display and semiquantitative RT-PCR we found, among other alterations, overexpression of the gene encoding the Core I subunit of the complex III of the mitochondrial respiratory chain in a follicular carcinoma composed of Hürthle cells.
\end{abstract}

Results: Similar high levels of Core I gene expression were detected in nine follicular carcinomas (seven with Hürthle cell features), in seven microfollicular adenomas (one with Hürthle cell features) and in one micro/macrofollicular adenoma, in contrast to a lower/normal expression in nine papillary carcinomas (three with Hürthle cell features) and five macrofollicular adenomas (one of which displaying Hürthle cell features). No significative correlation was found between Core I overexpression and the proliferative activity of the lesions.

Conclusions: We conclude that Core I overexpression in thyroid tumours is not associated with malignancy, Hürthle cells or proliferative activity. The pathogenetic mechanism linking Core I overexpression to the microfollicular pattern of growth of thyroid tumours remains to be clarified.

\section{Background}

Neoplastic progression is a prolonged and stepwise process involving a series of molecular alterations that culminate in invasion and metastasis. Such molecular alterations usually result in the modification of gene expression in cancer cells.
Some consistent molecular changes have been previously described in functioning thyroid adenomas - TShR and Gs alpha gene mutations - [1] as well as in papillary thyroid carcinomas: RET/PTC and trk rearrangement $[2,3]$ and $B$ RAF mutation [4]. For follicular adenomas and follicular carcinomas the picture is less clear if one excludes the 
relatively frequent occurrence of ras activation/mutation [5,6] and PAX8-PPARgamma1 fusion [7].

Carcinomas with Hürthle (oncocytic, oxyphilic) cell features typically harbour the genetic alterations associated to the predominant histotype of the lesion - e.g. the high prevalence of RET/PTC rearrangements and $B-R A F$ mutations in the Hürthle cell variant of papillary thyroid carcinomas $[4,8]$.

Haugen et. al. [9], using the differential display method, reported an increased expression of mitochondrial mRNA and mitochondrial proteins in a series of papillary thyroid carcinomas and advanced that such overexpression appeared to be associated with the increased number and/ or size of mitochondria, observed in most of the tumours.

In an attempt to identify genes putatively involved in the origin and/or development of follicular thyroid carcinomas composed of Hürthle cells we applied Liang's method of differential display [10] to one of such tumours and to the corresponding adjacent "normal" parenchyma. After having identified one of the genes overexpressed in the carcinoma as the Core I subunit of the complex ubiquinol-cytochrome $c$-reductase (complex III) of the mitochondrial respiratory chain (MRC), we compared its level of expression in the follicular Hürthle cell carcinoma with those observed in 30 additional cases of benign and malignant thyroid tumours with different histotypes, and with or without Hürthle cell features.

\section{Methods \\ Materials}

The study was performed in two steps. First it dealt with a case of follicular carcinoma composed of Hürthle cells. It was afterwards expanded in order to include, for comparative purposes, 30 thyroid tumours with or without Hürthle cell features. The 30 tumours were classified according to Rosai et al. [11] and Hedinger et al. [12] as follicular adenoma $(\mathrm{n}=13 ; 7$ microfollicular adenomas, 5 macrofollicular adenomas and one micro/macrofollicular adenoma), follicular carcinoma $(\mathrm{n}=8)$ and papillary carcinoma $(n=9)$. One of the microfollicular adenomas, one of the macrofollicular adenomas, six of the follicular carcinomas and three of the papillary carcinomas were composed of Hürthle cells. Frozen sections from each case were used to separate samples from the tumours and the respective adjacent normal parenchyma; samples were immediately collected, after surgical resection in the University Hospital of S. João, Porto, Portugal, quick frozen in liquid nitrogen and stored at $-70^{\circ} \mathrm{C}$.

\section{Immunohistochemistry}

Paraffin-embedded specimens were used in the immunohistochemical study. Serial sections were immunostained with monoclonal antibody for a human nuclear proliferation-associated antigen (MIB-1, Immunotech). Immunostaining was performed using the avidin-biotinperoxidase (ABC) complex as described by Holm et al. [13], with an additional step for microwave antigen retrieval $(5 \times 1.5 \mathrm{~min}$ at $750 \mathrm{~W})$. Previously tested positive controls were included in the series. As negative controls, immunoglobulins of the same subclass and in the same protein concentrations as the primary specific antibody were used. Evaluation of the percentage of immunoreactive cells for MIB-1 was made by counting 1000 tumour cells in random fields.

\section{Differential display (DD)}

Total RNA from 50-100 mg of frozen powdered lesions was isolated either using the acid guanidinium thiocyanate-phenol-chloroform extraction method as described by Chomczynski and Sacchi [14], or with Tripure ${ }^{\mathrm{TM}}$ Isolation Reagent (Roche Diagnostics Corporation, Indianapolis, IN, USA). In order to remove genomic DNA, samples were treated with $\mathrm{LiCl}$. An amount of $0.2 \mu \mathrm{g}$ of total RNA obtained from the follicular carcinoma and the correspondent adjacent normal tissue were reverse transcribed in a $20 \mu \mathrm{l}$ reaction volume using either $\mathrm{T}_{13} \mathrm{~A}, \mathrm{~T}_{13} \mathrm{G}$, or $\mathrm{T}_{13} \mathrm{C}$ (Table 1 ) and subsequently amplified by PCR using four different arbitrary primers: $\mathrm{D}_{390}, \mathrm{D}_{433}, \mathrm{D}_{492}, \mathrm{D}_{495}$ (Table 1 ) essentially as described [10]. The cycling parameters were the following: $94^{\circ} \mathrm{C}$ for $5 \mathrm{~min} ; 40$ cycles with $94^{\circ} \mathrm{C}$ for 30 $\mathrm{s}, 40^{\circ} \mathrm{C}$ for $1 \mathrm{~min}$ and $72^{\circ} \mathrm{C}$ for $2 \mathrm{~min}$; followed by $72^{\circ} \mathrm{C}$ for $10 \mathrm{~min}$. Duplicates were made for each primer combination and PCR was performed twice to confirm the results and eliminate false positives. To assure that the band patterns obtained in DD could not be originated from contaminating DNA, PCR was performed for all the primer combinations directly on the RNA from normal and tumour cells. In addition, PCR negatives controls were performed by replacing cDNA with water. PCR products were analyzed on a $6 \%$ sequencing gel. The cDNA bands of interest (unique to tumour or normal thyroid) were cut out of the gel, eluted and reamplified by PCR.

\section{Semiquantitative RT-PCR}

For each sample $1.0 \mu \mathrm{g}$ of RNA was reverse transcribed in a reaction volume of $20 \mu \mathrm{l}$ in the presence of $4 \mathrm{mM} \mathrm{dNTP,}$ $1.0 \mathrm{U}^{-1} \mathrm{l}^{-1}$ RNase Inhibitor, $2.5 \mu \mathrm{M}$ random primer $\mathrm{P}$

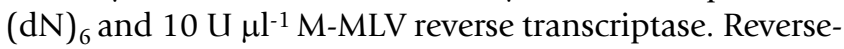
transcribed cDNAs $(0.25 \mu \mathrm{g})$ from normal and neoplastic tissues were co-amplified with a set of primers for the housekeeping gene $\beta$-actin (primers Actin-R and Actin-F) (Table 1) and a set of primers for the differentially expressed gene - Core I gene- (primers Core I-R and Core I-F) (Table 1). All the quantitations were done in triplicate. The PCR products were separated in an agarose gel $(2 \%)$, and stained with ethidium bromide. The intensity of the fluorescence was automatically measured and 
Table I: Primer sequences for DD and RT-PCR analysis.

\begin{tabular}{lll}
\hline Name & Length & Sequence (5' to 3') \\
\hline DD & & \\
TI3A & $14-\mathrm{mer}$ & TTTTTTTTTTTTTA \\
TI3G & $14-\mathrm{mer}$ & TTTTTTTTTTTTG \\
TI3C & $14-\mathrm{mer}$ & TTTTTTTTTTTTC \\
D390 & $10-\mathrm{mer}$ & GTTGCGATCC \\
D433 & $10-\mathrm{mer}$ & CTTGATTGCG \\
D492 & $10-\mathrm{mer}$ & CAGTGTAGTC \\
D495 & $10-\mathrm{mer}$ & TCGATACAGG \\
\hline RT-PCR & & \\
Core I R & $19-\mathrm{mer}$ & \\
Core I F & $19-\mathrm{mer}$ & GCAGAACTGTAGTCTGGAA \\
Actin R & $20-\mathrm{mer}$ & GGAGTAGTGCCATCTAGAT \\
Actin F & $21-\mathrm{mer}$ & ATGCTATCACCTCCCCTGTG \\
\end{tabular}

integrated using the genescan software "Image Master" (Pharmacia).

The optimal number of cycles of amplification to allow quantitation of Core I and $\beta$-actin genes PCR products was determined using a sample of normal thyroid and the same primers used for the semiquantitative PCR. Samples were subjected to a number of amplification cycles ranging from 10 to 30 cycles. PCR products were separated in a $2 \%$ agarose gel and stained with ethidium bromide. The intensity of the fluorescence was automatically measured and integrated using the genescan software "Image Master" (Pharmacia). A close to exponential increase in the amount of PCR product was obtained between 21 and 26 cycles for both Core I and $\beta$-actin products (Figure 1 ). In all of our RT-PCR experiments 24 cycles were used.

\section{Sequence analysis}

Sequencing of the cDNA fragments was performed using ABI PRISM ${ }^{\mathrm{TM}}$ DyeTerminator Cycle Sequencing Kit according to the protocol supplied by the manufacturer (Perkin Elmer). Sequencing reaction parameters were the following: $15 \mathrm{~s}$ at $94^{\circ} \mathrm{C}, 20 \mathrm{~s}$ at $45^{\circ} \mathrm{C}$ and $4 \mathrm{~min}$ at $60^{\circ} \mathrm{C}$ for 30 cycles. After purification and denaturation the sequencing products were loaded onto a $6 \%$ sequencing gel and runned for $7 \mathrm{~h}$ at $30 \mathrm{~W}$ constant power on an ABI PRISM ${ }^{\text {тм }}$ DNA sequencer.

\section{Comparison of the CDNA sequences with known sequences from GenBank database}

The nucleotide sequences obtained were compared with known sequences by searching the GenBank database with BLASTN and BLASTX $[15,16]$ programs. In order to confirm that the sequences determined for the isolated bands could actually be produced by the specific arbitrary primer, we performed an alignment between the aforementioned primer and the sequence of the putative gene. This alignment was accomplished using GeneJokey software for Macintosh (Taylor P L (1990) GeneJokey Sequence Processor, Biosoft, Cambridge) allowing up to three mismatches.

\section{Southern blot}

For Southern blot analysis, $10 \mu \mathrm{g}$ of DNA from normal

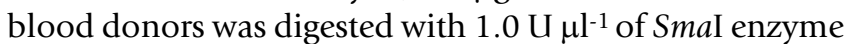
(Stratagene), separated by agarose gel $(0.8 \%)$ electrophoresis and transferred onto nylon filters (Hybond $\mathrm{N}^{+}$, Amersham). After blotting, the nylon membranes were prehybridized in a $0.5 \mathrm{M}$ sodium phosphate buffer, $1 \mathrm{mM}$ EDTA $\mathrm{pH}=8$ and $7 \%$ SDS. cDNA fragments were labelled by random priming according the protocol supplied by manufacturer (Amersham) using [ $\alpha-32 \mathrm{P}] \mathrm{dCTP}(\sim 3000 \mathrm{Ci} /$ $\mathrm{mmol}$ ). The probe was purified, denatured and added to the prehybridisation solution; the hybridisation was performed overnight at $65^{\circ} \mathrm{C}$. Nylon membranes were exposed to a x-ray film (Amersham-MP hyperfilms) at $70^{\circ} \mathrm{C}$. Band $\mathrm{T} 1$ (see Results) was reamplified, purified from $2 \%$ agarose gel and used as a probe. From the restriction map of Core I protein, band T1 was expected to hybridize with a $2.5 \mathrm{~Kb}$ fragment of human genomic DNA digested with SmaI.

\section{Construction and screening of a human thyroid cDNA library}

The cDNA library was constructed using a $\lambda$ ZAP express ${ }^{\circledast}$ cDNA cloning Kit and a gigapack ${ }^{\circledast}$ III Gold Kit (Stratagene $^{\varpi}$, La Jolla, CA) according to the manufacturer's instructions. Briefly, poly(A)+RNA was purified from total RNA isolated from normal human thyroid tissue by affinity chromatography using an oligo poly(dT) cellulose 


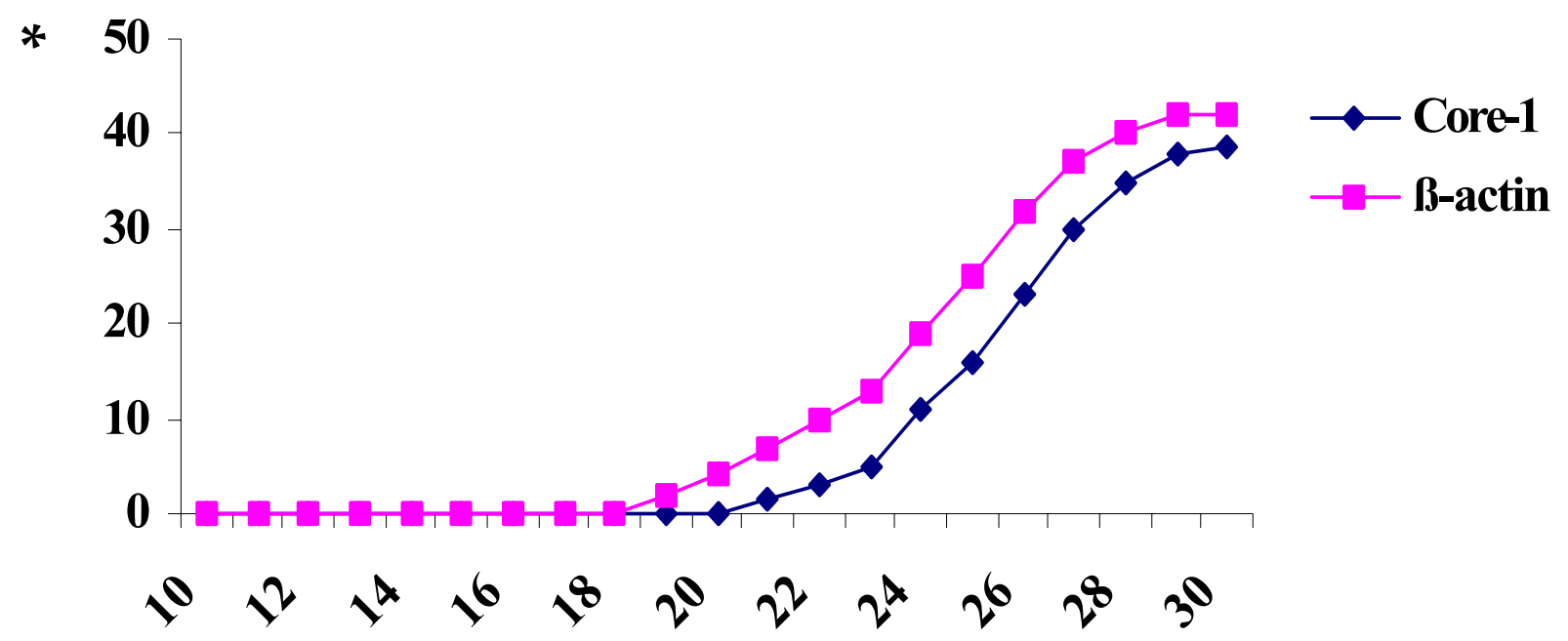

Cycles

A

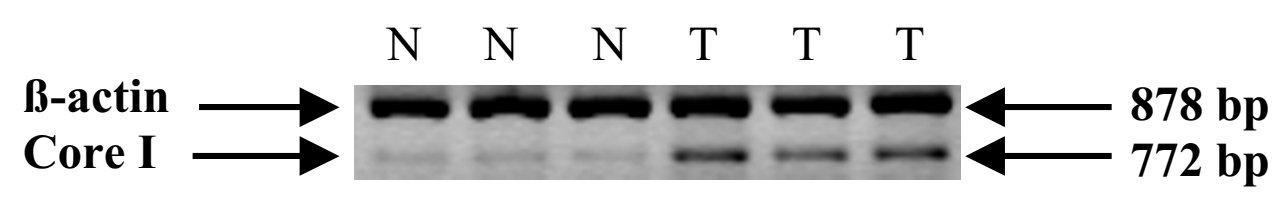

B

Figure I

Quantification of Core-I and $\beta$-actin mRNA by RT-PCR analysis. A. Determination of the optimal number of amplification cycles for quantification of Core-I and $\beta$-actin mRNA. B. Semiquantitative RT-PCR analysis of Core-I mRNA expression. For each sample, constant amounts of reverse-transcribed RNA were amplified together with $\beta$-actin housekeeping gene. $N$, triplicates of samples of normal thyroid tissue; $\mathrm{T}$, triplicates of samples of follicular carcinoma. * Values are expressed in arbitrary units. 
column (Poly (A) Quick ${ }^{\circledR}$ mRNA isolation Kit - Stratagene $^{\circledast}$, La Jolla, CA), and then used as a template for cDNA synthesis. Double-stranded cDNA inserts $(>0.5 \mathrm{~kb})$ were ligated to EcoRI and XhoI cloning sites in $\lambda$ ZAP express phage vector. The titer of the amplified library was $8.45 \times$ $10^{9} \mathrm{pfu} / \mathrm{ml}$, corresponding to $97.5 \%$ of recombinant phages. The corresponding to $1 \times 10^{6} \mathrm{pfu}$ of human thyroid cDNA library was screening using the cloned cDNA fragments isolated by differential display as described by the commercial supplier (Stratagene ${ }^{\circledast}$, La Jolla, CA). Inserts from the positive clones were sequenced by automated sequence analysis.

\section{Statistical analysis}

The analyses of the results of Core I gene expression were performed using the student t-test (Unpaired). For MIB-1 the correlation studies were performed using a simple regression test. A $p$ value $<0.05$ was considered statistically significant.

\section{Results \\ DD}

The DD analysis of mRNA revealed seven bands differentially expressed in normal thyroid tissue and in the follicular Hürthle cell carcinoma. Four bands (N1-N4) were present in normal tissue samples and displayed either a very weak signal or no detectable signal in the tumour samples; the remaining three bands (T1-T3) were present in the tumour samples and absent in the normal tissue samples (data not shown).

Limitations in the amount of tissue necessary for the molecular studies and, consequently, limitations in the available amount of RNA - unfortunately a common situation whenever surgical specimens are used - hindered us from performing confirmation of DD by Northern blot. To confirm the specificity and reproducibility of differentially expressed bands, DD analyses were repeated and duplicates of normal and tumour tissues were performed for all primer combinations. Furthermore, PCR negatives were run in a sequencing gel and after exposition to an autoradiographic film no signal was detected (data not shown). PCR was also performed without previous RT reaction; in these conditions no bands were originated (data not shown). These results ensure that there was no DNA contamination in the samples collected from the follicular Hürthle cell carcinoma and adjacent normal thyroid tissue.

\section{Reamplification by PCR}

Only six bands out of the seven differentially expressed bands were successfully reamplified by PCR (N1, N2, N3, $\mathrm{T} 1, \mathrm{~T} 2, \mathrm{~T} 3)$. The approximate lengths of the bands were determined, in a $2 \%$ agarose gel, as being about $200 \mathrm{bp}$, $200 \mathrm{bp}, 200 \mathrm{bp}, 300 \mathrm{bp}, 250 \mathrm{bp}$, and $250 \mathrm{bp}$ respectively.

\section{Sequencing}

Direct sequencing was possible only in band $\mathrm{T} 1$, in which there were 289 bases. cDNA fragments N1, N2, N3, T2 and $\mathrm{T} 3$ were cloned into the $\mathrm{PCR}{ }^{\circledR} 2.1$ vector using the TA Cloning System Kit (Invitrogen ${ }^{\circledR}$ ) according to the manufacturer's instructions and sequenced using the M13 vector primers giving reading sequences of $192 \mathrm{bp}, 170 \mathrm{bp}$, 172 bp, 239 bp and 242 bp respectively.

\section{Homology search}

Regarding bands N2 and N3, the homology search did not lead to the identification of any previously known gene (data not shown). The 192 bp cDNA fragment from band N1 had 100\% homology to Homo sapiens thyroglobulin gene (Accession nr: AF305872). The 289 bp cDNA fragment from band $\mathrm{T} 1$ had $98 \%$ homology to human Core I protein (Accession nr: AW075678). The 239 bp cDNA fragment from band T2 had 100\% homology to rRNA 28s (Accession nr: M11167) and the 242 bp cDNA fragment from band T3 had 100\% homology to Homo sapiens mRNA for KIAA1468 protein (Accession nr: AB040901).

\section{Southern blot confirmation}

To confirm that the sequence of band $\mathrm{T} 1$ corresponds to the human Core I gene, band T1 was used as a probe in Southern blot analysis. Hybridization with a fragment of SmaI digested human genomic DNA of the expected size (2.5 Kb) (see Methods) confirmed the results obtained by the homology search. Our conclusion is also supported by the presence of the arbitrary primer sequence in the sequence of Core I protein mRNA near the 5' end of the gene. The predicted annealing position determines the synthesis of a cDNA fragment with $274 \mathrm{bp}$, approximately the length of band $\mathrm{T} 1$.

\section{Screening of the human thyroid cDNA library}

The cDNA library was screened using the cDNA fragments isolated by DD, that did not show any homology with known genes. The screening process using band N2 as a radiolabelled probe led to the isolation of positive clones. The insert of one of the clones was sequenced and the search for homology using the GenBank database showed that the clone had $97 \%$ homology to human ribosomal protein L3 (Accession nr: X73460). The screening process using band $\mathrm{N} 3$ as a radiolabelled probe lead to the isolation of positive clones. The insert of one of the clones was sequenced and the search for homology using the GenBank database showed that the clone had 97\% homology to Homo sapiens hypothetical gene (LOC125510), mRNA (Accession nr: XM_074963).

\section{Follicular Hürthle cell carcinoma vs normal thyroid}

The results obtained in the study of the follicular Hürthle cell carcinoma are summarized in Table 2. 
Table 2: Summary of the data on differentially expressed genes in the follicular Hürthle cell carcinoma.

\begin{tabular}{ll}
\hline Genes overexpressed in the tumour: & $-\mathrm{TI}$ (Core I protein) \\
& $-\mathrm{T} 2$ (rRNA 28s) \\
& $-\mathrm{T} 3$ (Homo sapiens mRNA for KIAAI468 protein) \\
\hline Genes underexpressed in the tumour: & $-\mathrm{NI}$ (Homo sapiens thyroglobulin gene) \\
& $-\mathrm{N} 2$ (ribosomal protein L3) \\
& $-\mathrm{N} 3$ (Homo sapiens hypothetical gene (LOCI255I0), mRNA) \\
& $-\mathrm{N} 4$ (not determined for technical reasons) \\
\hline
\end{tabular}

Table 3: RT-PCR. Level of expression of Core $I$ in tumours and corresponding normal tissues.

\begin{tabular}{|c|c|c|c|c|c|}
\hline Case Age/Sex & Diagnosis & $\begin{array}{c}\text { Tumour Core I/ } \\
\text { Actin } \%^{\mathrm{a}}\end{array}$ & $\begin{array}{c}\text { Normal Core I/ } \\
\text { Actin \%a }\end{array}$ & $\begin{array}{l}\text { Level of Expression } \\
*\end{array}$ & MIB-Ib \% \\
\hline I $64 / F$ & HFC & $46.2 \pm 0.3$ & $21.0 \pm 0.5$ & 2.2 & I.I \\
\hline $233 / M$ & HFC & $52.1 \pm 1.8$ & $22.8 \pm 1.3$ & 2.3 & 1.0 \\
\hline $347 / M$ & HFC & $52.1 \pm 2.2$ & $24.8 \pm 1.1$ & 2.1 & 0.9 \\
\hline $459 / F$ & HFC & $54.6 \pm 0.8$ & $22.2 \pm 1.0$ & 2.5 & 0.5 \\
\hline $555 / F$ & HFC & $47.7 \pm 1.2$ & $22.7 \pm 0.8$ & 2.1 & 0.9 \\
\hline $624 / F$ & HFC & $50.2 \pm 0.9$ & $23.9 \pm 1.2$ & 2.1 & 0.9 \\
\hline $755 / F$ & HFC & $41.5 \pm 1.2$ & $21.9 \pm 1.4$ & 1.9 & 0.8 \\
\hline $864 / F$ & $\mathrm{FC}$ & $46.4 \pm 2.8$ & $25.8 \pm 1.6$ & 1.8 & I.I \\
\hline $946 / F$ & FC & $48.9 \pm 2.1$ & $23.4 \pm 0.8$ & 2.1 & 1.6 \\
\hline $1071 / \mathrm{F}$ & $\mathrm{HmFA}$ & $47.2 \pm 2.7$ & $22.6 \pm 1.8$ & 2.1 & I.I \\
\hline II 24/F & $\mathrm{mFA}$ & $47.3 \pm 3.3$ & $26.4 \pm 0.8$ & 1.8 & 0.3 \\
\hline $1269 / F$ & mFA & $45.1 \pm 2.3$ & $27.6 \pm 1.3$ & 1.6 & 0.0 \\
\hline $1357 / F$ & mFA & $42.8 \pm 1.8$ & $22.5 \pm 0.9$ & 1.9 & 0.5 \\
\hline $1427 / F$ & mFA & $48.8 \pm 2.2$ & $23.2 \pm 1.1$ & 2.1 & 0.9 \\
\hline 15 53/F & mFA & $49.0 \pm 2.1$ & $22.7 \pm 0.8$ & 2.2 & 1.1 \\
\hline $1665 / F$ & mFA & $52.4 \pm 2.4$ & $24.9 \pm 0.9$ & 2.1 & 0.7 \\
\hline $1731 / \mathrm{F}$ & mMFA & $35.8 \pm 2.3$ & $27.6 \pm 1.3$ & 1.3 & 0.1 \\
\hline $1852 / F$ & PC & $30.0 \pm 0.2$ & $27.3 \pm 0.1$ & I.I & 0.7 \\
\hline $1946 / \mathrm{F}$ & PC & $24.2 \pm 0.5$ & $26.9 \pm 0.1$ & 0.9 & 1.1 \\
\hline $2052 / \mathrm{F}$ & PC & $39.8 \pm 2.6$ & $37.3 \pm 0.0$ & 1.1 & 0.7 \\
\hline $2147 / F$ & PC & $26.7 \pm 3.4$ & $33.5 \pm 3.7$ & 0.8 & 3.0 \\
\hline $2252 / \mathrm{F}$ & PC & $16.7 \pm 0.6$ & $24.6 \pm 0.4$ & 0.7 & 0.7 \\
\hline 23 68/F & PC & $24.1 \pm 0.8$ & $24.0 \pm 0.6$ & 1.0 & 0.8 \\
\hline $2460 / F$ & HPC & $20.9 \pm 1.2$ & $23.2 \pm 0.9$ & 0.9 & 1.5 \\
\hline $2562 / F$ & HPC & $16.4 \pm 1.2$ & $22.2 \pm 0.8$ & 0.7 & 0.4 \\
\hline $26 \mathrm{II} / \mathrm{M}$ & HPC & $27.4 \pm 0.9$ & $22.8 \pm 2.1$ & 1.2 & I.I \\
\hline $2730 / F$ & HMFA & $19.9 \pm 0.1$ & $28.6 \pm 2.3$ & 0.7 & 0.4 \\
\hline $2842 / F$ & MFA & $18.5 \pm 0.1$ & $24.8 \pm 0.1$ & 0.7 & 0.6 \\
\hline $2952 / F$ & MFA & $22.7 \pm 2.3$ & $25.4 \pm 0.3$ & 0.9 & 1.0 \\
\hline $3062 / F$ & MFA & $22.3 \pm 0.2$ & $23.0 \pm 0.1$ & 1.0 & 0.2 \\
\hline $3154 / F$ & MFA & $20.9 \pm 0.7$ & $25.8 \pm 0.8$ & 0.8 & 0.9 \\
\hline
\end{tabular}

F - Female; M - Male; HFC - Follicular carcinoma composed of Hürthle cells; FC - Follicular carcinoma; PC - Papillary carcinoma; HPC - Papillary carcinoma composed of Hürthle cells; mFA - Microfollicular adenoma; MFA - Macrofollicular adenoma; mMFA - Micro/macrofollicular adenoma; HmFA - Microfollicular adenoma composed of Hürthle cells; HMFA - Macrofollicular adenoma composed of Hürthle cells; Core I/Actin - Ratio between the expression of Core I gene and $\beta$-actin gene. *Values are expressed as ratio between the mean values obtained in tumours and normal tissues (previous columns). aResults are expressed as mean \pm s.d. of three experiments. bOnly tumoural MIB-I indexes are shown. 


\section{Semiquantitative $R T-P C R$}

Semiquantitative RT-PCR showed that the level of Core I is 2.2 fold higher in the follicular Hürthle cell carcinoma than in the adjacent normal thyroid tissue (case 1) (Table 3).

Semiquantitative RT-PCR was also performed in the remaining 30 cases. The results of this analysis are summarized in Table 3. Sixteen of the cases (eight follicular carcinomas, seven microfollicular adenomas and a micro/ macrofollicular adenoma) showed overexpression (1.32.5 times higher) of Core I protein in tumour tissue. Four tumours (two papillary carcinomas and two macrofollicular adenomas) presented lower expression ( $<0.8$ times) of this gene in tumour tissue than in the normal counterpart. In seven papillary carcinomas and in three microfollicular adenomas the levels of expression were similar ( $\geq 0.8$ times and $\leq 1.2$ times) in tumour and normal tissue (Table 3). The levels of expression in microfollicular and macrofollicular adenomas, as well as in follicular carcinomas and papillary carcinomas were similar regardless of the presence or absence of Hürthle cell features (Table 3).

\section{Immunohistochemistry}

The MIB-1 index of the 31 cases is shown in Table 3. No significative correlation between MIB-1 index and level of expression of Core I protein was found ( $p=0.927)$.

\section{Statistical analysis}

The statistical analysis of the RT-PCR results revealed similar relatively low levels of expression of Core I gene in the five macrofollicular adenomas (mean \pm standard deviation: $0.82 \pm 0.13)$ and in nine papillary carcinomas $(0.93$ \pm 0.18 ), as well high levels of expression in the seven microfollicular adenomas $(1.97 \pm 0.21)$ and nine follicular carcinomas $(2.12 \pm 0.21)$. The expression levels observed in macrofollicular adenomas and in papillary carcinomas were significantly lower $(p<0.0001$ and $p<$ 0.0001 , respectively) than those observed in microfollicular adenomas and in follicular carcinomas $(p<0.0001$ and $p<0.0001$, respectively) regardless of the presence or absence of Hürthle cell features. No significant difference was found between the expression of Core I gene in malignant tumours and benign tumours $(p=0.824)$.

\section{Discussion}

Using a DD approach we were able to identify six out of seven differentially expressed cDNA fragments: N1, N2, N3, T1, T2 and T3 corresponding to Homo sapiens thyroglobulin gene, ribosomal protein L3, Homo sapiens hypothetical gene (LOC125510) mRNA, human Core I protein, rRNA 28s and Homo sapiens mRNA for KIAA1468 protein, respectively.
The most interesting findings concern the overexpression (differential expression) of the gene that encodes Core I protein in the follicular Hürthle cell carcinoma of the thyroid. Core I protein is a subunit of the complex III of the $\mathrm{MRC}$ that is located in the inner membrane of the mitochondrion and is encoded by a nuclear gene [17]. The complex III is a transmembrane complex of the inner mitochondrial membrane encoded by nuclear and mitochondrial genes, and its electron-carrier function is essential for oxidative phosphorylation (OXPHOS) [17].

The detection of a differentially expressed gene encoding for Core I protein in a follicular carcinoma composed of Hürthle cells led us to hypothesize that such a finding might be related to the prominent mitochondrial abnormalities that are the hallmark of this type of tumours [18]. In order to explore this possibility we analyzed the expression of Core I gene in 30 additional benign and malignant lesions of the thyroid, with or without Hürthle cell features. We detected Core I protein overexpression in several of these lesions, thus ruling out the putative association between Core I protein overexpression and Hürthle cell features.

Our data do not fit those recently reported by Haugen et. al. [9], who have also used a DD approach to study the expression of mitochondrial-related genes in several thyroid tumours. Haugen et. al. [9] found in papillary carcinomas and in some other types of thyroid tumours overexpression of the following mitochondrial genes that encode for proteins of the OXPHOS system: NADH dehydrogenase 5, ATP synthase 6, cytochrome b and cytochrome c oxidase I.

Our finding of Core I protein overexpression in some adenomas shows, on the other hand, that such overexpression should not be linked to malignancy.

We observed, furthermore, that Core I protein overexpression was restricted to follicular carcinomas and to adenomas with a microfollicular morphology in contrast with its lower expression in macrofollicular adenomas. Interestingly, an intermediate level of expression was found in case 8 , an adenoma displaying both macro and microfollicular areas (Table 3).

At variance with microfollicular adenomas and follicular carcinomas, levels of Core I expression in papillary carcinomas were near-normal in all samples, regardless of having or not Hürthle cell features.

One might assume that the overexpression of Core I protein in follicular carcinomas and microfollicular adenomas could be associated with an increased proliferative activity of such thyroid neoplasms. The results we 
obtained in the study of MIB-1 expression did not reveal, however, any significative relationship between proliferative activity and Core I overexpression.

Taking into consideration the aforementioned results and the association between Core I overexpression and the microfollicular architecture of the thyroid lesions it seems conceivable to suggest that the overexpression of Core I protein may be linked to a putative higher metabolism of microfollicular tumours. In mammals, different tissues have been shown to vary substantially in mitochondrial energy production. Such differences could result from changes in mtDNA amount or from the differential expression of nDNA OXPHOS genes [19]. It would be interesting to study some hyperfunctioning thyroid lesions, such as Grave's disease and toxic adenomas, to find whether or not Core I protein is also overexpressed in those lesions.

Alterations in the expression of OXPHOS enzymes have been described in polyps of familial polyposis coli patients [20], transformed cell lines [21], renal carcinomas and renal and salivary oncocytomas [22], melanoma cells [23], prostate carcinoma [24] and breast carcinoma [25].

We are not aware, however, of any study reporting the overexpression of Core I protein in any of the aforementioned models. The same holds true regarding thyroid tumours in which no alterations have been reported to data, to the best of our knowledge, in the Core I subunit of complex III.

The other differentially expressed fragments - N1, N2, N3, $\mathrm{T} 2$ and T3 - raise a number of different issues.

The identification of genes encoding ribosomal proteins as being differentially expressed in tumour cells when compared with their normal counterparts has been previously reported $[23,26]$. In our study, the gene that encodes for ribosomal protein L3 was found to be expressed at higher levels in normal thyroid tissue than in the follicular Hürthle cell carcinoma. Graack et al. [27] described a nucleus-encoded mitochondrial ribosomal protein in yeast, YmL9, that was found to be essential for mitochondrial ribosomal function and to have a high sequence and genetic similarity to human ribosomal protein L3. According to this, Graack et al. [27] postulated that cytoplasmic ribosomal protein L3 could be a nucleusencoded mitochondrial ribosomal protein required for protein synthesis by functional mitochondria. Since Hürthle cells are characterized by a deficient protein production and an increased number of "abnormal" mitochondria [28] it is tempting to hypothesize that the lower expression of ribosomal protein L3 in Hürthle cells may be related to an intrinsic defect of Hürthle cells. Further studies are obviously needed to confirm our finding and, in the affirmative case, to verify if there is any relationship between Hürthle cell features and underexpression of human ribosomal protein $\mathrm{L} 3$.

The differential expression of a rRNA $28 \mathrm{~s}$ in the conditions we have used - a DD technique using total RNA - is considered to reflect a technical artifact and should not therefore lead to any biopathological interpretation [10].

The Homo sapiens hypothetical gene (LOC125510) and the Homo sapiens KIAA1468 protein are proteins with unknown function.

The loss of expression of thyroglobulin gene in the tumoural tissue was expected due to the loss of differentiation of tumour cells.

\section{Conclusions}

Summing up, we found overexpression of the gene encoding the Core I subunit of the complex III of MRC in follicular carcinomas and microfollicular adenomas of the thyroid with or without Hürthle cells features, in contrast with its underexpression in macrofollicular adenomas and its near-normal levels in papillary carcinomas. No significative correlation was found between Core I overexpression and the proliferative activity of the lesions. The study of a large series of follicular lesions appears to be necessary to clarify the pathogenetic mechanism linking Core I overexpression to the microfollicular pattern of growth of thyroid tumours.

\section{Competing interests}

None declared.

\section{Authors' contributions}

VM performed semiquantitative RT-PCR and sequence analysis, comparison of cDNA sequences with known sequences from GenBank database, southern blot and statistical analysis. AP carried out the comparison of cDNA sequences with known sequences from GenBank database and construction and screening of a human thyroid cDNA library. AC performed the Differential display analysis. PS and ASR carried out immunohistochemistry. JCM helped in the semiquantitative RT-PCR analysis. MSS performed tumour classification. All the authors contributed to the drafting of the manuscript.

\section{Acknowledgements}

This study was partially supported by two Ph.D. Grants (PRAXIS XXI/BD/ $21795 / 99$ - AP, FSRH/BD/2I 775/99 - ASR) and by a Post-Doc Grant (SFRH/BPD/I4594/2003 - VM) from the Portuguese Science and Technology Foundation (FCT) and by further funding from the same source (Project - POCT/4I055/NSE/200I). 


\section{References}

I. Tonacchera M, Vitti P, Agretti P, Ceccarini G, Perri A, Cavaliere R, Mazzi B, Naccarato AG, Viacava P, Miccoli P, Pinchera A, Chiovato L: Functioning and nonfunctioning thyroid adenomas involve different molecular pathogenetic mechanisms. J Clin Endocrinol Metab 1999, 84:4I55-4I58.

2. Fusco A, Grieco M, Santoro M, Berlingieri MT, Pilotti S, Pierotti MA, Della Porta G, Vecchio G: A new oncogene in human thyroid papillary carcinomas and their lymph-nodal metastases. Nature 1987, 328: I70-I72.

3. Bongarzone I, Pierotti MA, Monzini N, Mondellini P, Manenti G, Donghi R, Pilotti S, Grieco M, Santoro M, Fusco A, Vechio G, Della Porta G: High frequency of activation of tyrosine kinase oncogenes in human papillary thyroid carcinoma. Oncogene 1989 , 4:|457-|462.

4. Soares P, Trovisco V, Rocha AS, Lima J, Castro P, Preto A, Máximo V, Botelho T, Seruca R, Sobrinho-Simões M: BRAF mutations and RET/PTC rearrangements are alternative events in the etiopathogenesis of PTC. Oncogene 2003, 22:4578-4580.

5. Suarez HG, Du Villard JA, Caillou B, Schlumberger M, Tubiana M, Par mentier $C$, Monier $R$ : Detection of activated ras oncogenes in human thyroid carcinomas. Oncogene 1988, 2:403-406.

6. Wright PA, Lemoine NR, Mayall ES, Wyllie FS, Hughes D, Williams ED, Wynford-Thomas D: Papillary and follicular thyroid carcinomas show a different pattern of ras oncogene mutation. $\mathrm{Br}$ J Cancer 1989, 60:576-577.

7. Kroll TG, Sarraf P, Pecciarini L, Chen C), Mueller E, Spiegelman BM, Fletcher JA: PAX8-PPARgammal fusion oncogene in human thyroid carcinoma. Science 2000, 289: I357-I360.

8. Cheung CC, Ezzat S, Ramyar L, Freeman JL, Asa SL: Molecular basis of hürthle cell papillary thyroid carcinoma. J Clin Endocrinol Metab 2000, 85:878-882.

9. Haugen DR, Fluge O, Reigstad LJ, Varhaug JE, Lillehaug JR: Increased expression of genes encoding mitochondrial proteins in papillary thyroid carcinomas. Thyroid 2003, | 3:6 |3-620.

10. Liang P, Pardee AB: Differential display of eukaryotic mRNA by means of the polymerase chain reaction. Science 1992 257:967-97I.

II. Rosai J, Carcangiu ML, DeLellis RA: Tumours of the thyroid gland. In Atlas of Tumour Pathology. 3rd series. Edited by Armed Forces Institute of Pathology. Washington 1992.

12. Hedinger C, Williams ED, Sobin LH: The WHO histological classification of thyroid tumours: a commentary on the second edition. Cancer 1989, 63:908-911.

13. Holm R, Sobrinho-Simoes M, Nesland JM, Gould VE, Johannessen JV: Medullary carcinoma of the thyroid gland: an immunocytochemical study. Ultrastruct Pathol | 985, 8:25-4I.

14. Chomczynski P, Sacchi N: Single-step method of RNA isolation by acid guanidinium thiocyanate-phenol-chloroform extraction. Anal Biochem 1987, I62:156-I59.

15. Altschul SF, Gish W, Miller W, Myers EW, Lipman DJ: Basic local alignment search tool. I Mol Biol 1990, 2 I 5:403-4I0.

16. Gish W, States DJ: Identification of protein coding regions by database similarity search. Nat Genet 1993, 3:266-272

17. Wallace DC: Diseases of the mitochondrial DNA. Annu Rev Biochem 1992, 61:1175-1212.

18. Nesland JM, Sobrinho-Simões MA, Holm R, Sambade MC, Johannessen JV: Hürthle-cell lesions of the thyroid: a combined study using transmission electron microscopy, scanning electron microscopy, and immunocytochemistry. Ultrastruct Pathol I985, 8:269-290.

19. Brown MD, Wallace DC: Molecular basis of mitochondrial DNA disease. J Bioenerg Biomembr 1994, 26:273-289.

20. Yamamoto A, Horai S, Yuasa Y: Increased level of mitochondrial gene expression in polyps of familial polyposis coli patients. Biochem Biophys Res Commun 1989, I 59: I 100-I 106.

21. Torroni A, Stepien G, Hodge JA, Wallace DC: Neoplastic transformation is associated with coordinate induction of nuclear and cytoplasmic oxidative phosphorylation genes. J Biol Chem 1990, 265:20589-20593.

22. Heddi A, Faure-Vigny $H$, Wallace DC, Stepien G: Coordinate expression of nuclear and mitochondrial genes involved in energy production in carcinoma and oncocytoma. Biochim Biophys Acta 1996, I 3 | 6:203-209.

23. Simon HG, Risse B, Jost M, Oppenheimer S, Kari C, Rodeck U: Identification of differentially expressed messenger RNAs in human melanocytes and melanoma cells. Cancer Res 1996 56:3।|2-3। 17

24. Wang FL, Wang Y, Wong WK, Liu Y, Addivinola FJ, Liang P, Chen LB, Kantoff PW, Pardee AB: Two differentially expressed genes in normal human prostate tissue and in carcinoma. Cancer Res 1996, 56:3634-3637.

25. Sharp MG, Adams SM, Walker RA, Brammar WJ, Varley JM: Differential expression of the mitochondrial gene cytochrome oxidase II in benign and malignant breast tissue. J Pathol I992, 168:163-168

26. Barnard GF, Staniunas RJ, Mori M, Puder M, Jussup MJ, Steele G, Chen LB: Gastric and hepatocellular carcinomas do not express the same ribosomal protein messenger RNAs as colonic carcinoma. Cancer Res 1993, 53:4048-4052.

27. Graack HR, Grohmann L, Kitakawa M, Schäfer KL, Kruft V: YmL9, a nucleus-encoded mitochondria ribosomal protein of yeast, is homologous to L3 ribosomal proteins from all natural kingdoms and photosynthetic organelles. Eur J Biochem 1992 206:373-380.

28. Roediger WEW: The oxyphil and $\mathbf{C}$ cells of the human thyroid gland. A cytochemical and histopathologic review. Cancer 1975, 36:1758-1770

\section{Pre-publication history}

The pre-publication history for this paper can be accessed here:

http://www.biomedcentral.com/1471-2407/4/12/prepub
Publish with Bio Med Central and every scientist can read your work free of charge

"BioMed Central will be the most significant development for disseminating the results of biomedical research in our lifetime. "

Sir Paul Nurse, Cancer Research UK

Your research papers will be:

- available free of charge to the entire biomedical community

- peer reviewed and published immediately upon acceptance

- cited in PubMed and archived on PubMed Central

- yours - you keep the copyright 